\title{
The Historical Antecedents of Hamas
}

\author{
Nasir Faeq ${ }^{1}$; Diego Jahnata ${ }^{2}$ \\ ${ }^{1}$ Programme in History, Culture and Arts Studies, University of Turku, Finland \\ ${ }^{2}$ Programme in Law, University of Turku, Finland \\ di_font1981@utu.fi
}

\begin{abstract}
One of the unresolved dilemmas in the Israeli-Palestinian peace process is whether peace is possible without, or feasible with, Hamas. This article seeks to explain why Israeli policies have thus far failed and why inclusion of Hamas in the peace process is more likely to produce a lasting peace. Using data drawn from interviews, fieldwork and surveys, and theoretical perspectives from peace and social movement studies, the article analyses the evolution Hamas has undergone since its inception and how changes in its leadership, constituency and political culture have affected the movement's attitudes towards peace and compromise.
\end{abstract}

Keyword: Israeli-Palestinian, Hamas; Peace

\section{Introduction}

The conflict over Palestine is deeply rooted in ideological, religious, and national divisions which is built up for decades. This thesis examines the historical context, ideology, and structures of power that animated relations between Israeli Jews and Arab Palestinians during the twentieth century. The current thesis analyzed the reasons for the insoluble nature of the Palestinian-Israeli conflict. The reasons behind the continuation of the conflict are various. However, this thesis mainly concentrated on the ones stemmed from the clash of Palestinian and Jewish religious nationalism. This conflict represents the failure of both sides in making any concession from their territorial attachments which resulted from Arab nationalism and Zionism. Though both religious nationalisms ideologies were constructed on the same founding factors such as religion, territory and culture, Arab nationalists and Zionists gained different positions during the conflict. These positions determined the future of all of the peace processes in the near past. The thesis investigated the Israeli-Palestinian peace agreement of 1993-2000 (the Oslo Accords) by placing it in the historical and constructivist perspective. It started by showing how the Oslo Accords were inspired by the legacy of peacemaking in the Arab-Israeli conflict, which stipulated peacemaking between states, and contends that this factor had far-reaching implications for the way the Israeli-Palestinian conflict. This dissertation analyzed the Oslo Declaration of Principles of 1993, and asks why it failed. It is concluded that the role of religious nationalism in the Israeli-Palestinian conflict is highlighted specially after the Oslo Accords and future peace will be with the participation all affected groups (Hamami, 1994). 
Hamas (Arabic: حماس Hamās, an acronym of حركة المقاومة الاسلامية Harakat al-Muqāwamah al'Islāmiyyah [Islamic Resistance Movement]) is a Palestinian Sunni-Islamic fundamentalist militant organization.It has a social service wing, Dawah, and a military wing, the Izz ad-Din al-Qassam Brigades. It has been the de facto governing authority of the Gaza Strip since its takeover of that area in 2007. During this period, it fought several wars with Israel.Israel, the United States and the European Union classify, either in whole or in part, Hamas as a terrorist organization. This classification is one among various and diverse international positions on the nature of Hamas. Iran, Russia, China, and Turkey are some countries that view Hamas in a positive light (Litvak, 1998).

The Israel-Palestine conflict remains a crucial issue in international affairs, especially when the relations between Islamic and Western countries are considered. People and government units from Arabic, Muslim, and Western countries have become increasingly concerned with the progress of this conflict. The challenge that Israel poses to the Arab-Muslim world is unique in that it has neither precedent nor parallel in Islamic history(Faruqi, 1980). From the perspective of Muslims, Palestine is an Islamic cause (Nusse, 1998) and its conflict with Israel is ,the crucible of the conflicts affecting the Muslim ummah" that has ,acted as the epicentre of global jihad"e for many decades (Bonney, 2004). To validate these claims, several polls have been conducted in Arab and Muslim countries over the past years, and the poll results consistently show that the majority of Arabs and Muslims consider Palestine a central issue (Hirst, 2003).

From March 2010 to May 2010, the Pew Research Center conducted a poll and found that 97\% of Egyptians and Jordanians, 72\% of Indonesians, 63\% of Turks, and 59\% of Pakistanis sympathized with the Palestinians (Kohut, Doherty, \& Wike, 2012). The similar attitudes of Muslim Lebanese, Jordanians, Palestinians, and Syrians toward Israel are mainly unified by ,the role of religion in society and perceptions toward Israel ${ }^{\text {lee }}$ (Khashan, 2000). A study on the causes and effects of Middle Eastern conflicts, which have been ongoing since 1945, suggested that the conflicts between Islamic and Western countries could be mitigated by resolving the Israel-Palestine conflict beforehand (Milton Edwards \& Hinchcliffe, 2009).

Despite their remoteness from its core, Westerners are also highly concerned about the IsraelPalestine conflict. In a January 2005 report from the Pew Research Center, 85\% of Americans considered such conflict as a central goal of US foreign policies. Of this number, a respective 58\% and $42 \%$ suggested that these policies should give critical and high priority to the resolution of such dispute. Such proportions have remained consistent to some degree since the launch of these polls in 1993 (Ibid). Moreover, most Americans believe that the resolution of the Israel-Palestine conflict is the key to winning the ,war on

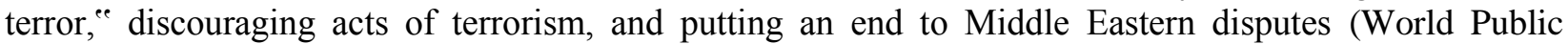
Opinion.Org, 2006).

However, despite the willingness of several countries to collaborate in resolving such disputes, the conflict between Israel and Palestine persists because of several factors, including the existence of international laws, the asymmetry of the conflicting parties, the role of the US military, the diplomatic and financial support of Western countries to Israel, and the absence of a religious dimension to facilitate the peace process.

The Israel-Palestine conflict is also characterized by an immense asymmetry in terms of the military, political, diplomatic, arid economic power of the conflicting parties as well as a profound disparity in the image of Israelis and Palestinians in the West. The ,peace process ${ }^{\text {ee }}$ has failed to achieve peace largely on account of an insistence on negotiations between the parties, despite their asymmetry and for its almost complete neglect of religious nationalism ideology (Rubenberg, 2003). From the Palestinian perspective, the conflict is a struggle for the right to "self-determination without external interference ${ }^{\text {;e }}$ the right to „national independence and sovereignty" ; and the right to ,return to homes and property from which they have been displaced and uprooted ${ }^{\text {ee }}$. From the Israeli perspective, it is a struggle to ensure such claims are 
not realized for they are considered detrimental to Zionist ambitions, including the survival and prosperity of the Jewish state.

Both the Israeli and Palestinian governments are challenged by the role of religion in resolving the conflict, and these challenges mostly lie within their respective boundaries. One of these conflicts materialized in the case of Hanan Ashrawi (2014), a Palestinian Christian who was appointed as the representative of Jerusalem to the Palestinian National Authority and served as the former spokeswoman for the Palestinian Liberation Organization (PLO) during the Oslo Peace Process. After she was asked about the alleged poor treatment of Christians on the hands of Muslims within the Palestinian Authority, Ashrawi, a long-time adversary of late Palestinian Prime Minister Yasser Arafat, responded as follows: „Quite the contrary. Arafat was much more conscious of supporting the Christians than I was, because I don "t look at people on the basis of their faith or their religion. I believe in separation of church and state."

Palestinians define their identities within the cultural, political, and historical assertion about the existence of Palestinians and a Palestinian territory. These people assert that international laws must recognize and protect each ethnic group in the world. The disenfranchisement of Palestine was attributed to the role of England in ending the Ottoman Empire. Specifically, as Arabs, the Palestinians strongly opposed the anti-Semitic acts that Jews suffered at the hands of Europeans and which eventually drove them to immigrate to Palestine during the late 1800 s and early 1900 s.

This thesis examines the conflict and struggle between Israel and Palestine, particularly in the period following the Oslo Agreement of 1993. Ideology questions are central to the Israeli-Palestinian conflict. In order to better understand the process of land ownership and transfer during different periods of Palestine ${ }^{\text {ee }} \mathrm{s}$ modern history, it is necessary to have briefly review land issues during the Ottoman rule, the period of the British Mandate, after the imposition of the Israeli state, and in the period after the 1967 War and then begin to assess what the impact of these different periods may have had on Palestinian communities. The historical revision of the struggle over land during the last four decades of Ottoman rule until the signing of the Oslo Agreement clarifies and reinforces the significance of the struggle which took place in the last decade of the twentieth century. The Oslo Accords and subsequent summits failed to produce successful negotiations between Israelis and Palestinians, further enabling spin tactics and blame- throwing to take precedence over the lived reality of the issues and reducing what could be starting points for reconciliation to rhetorical tools for dominance.

The religious idiom has always played an important role in the evolution of Palestinian nationalism and Jewish nationalism in the Palestinian-Israeli conflict. In the past, however, it was mostly the nationalist Palestinian elites- the notables during the British Mandate and the Fatah movement since the early 1960sthat employed Islamic symbols and themes in order to mobilize popular support for the national cause, whose aims were largely political and secular. Various Arab rulers have also used Islam as an instrument for their policies in the conflict (Bonney, 2004).

The conflict between Israel and the Palestinians has been at the forefront of international attention for more than sixty years, and its roots stretch back more than sixty years before that. The conflict has greatly affected the neighboring regions as well as the foreign policies of distant nations. The fundamental issue is a fight over possession of the territory of Palestine. Jewish immigrants and their descendants, guided by the nationalistic ideology of Zionism, and the Palestinian Arab inhabitants, among whom the Zionists settled, both claim an exclusive right to inhabit and control some or all of Palestine. Zionism has been the main enemy of Palestinian Arabs, and it is not possible to analyses the evolution of Palestinian nationalism without understanding the importance of Palestinian opposition to Zionism. 
The thesis statement is important because it answers the reader's question, why the PalestinianIsraeli conflict has remained irreconcilable for decades and why the Oslo Accords has failed. While the details and forms of the conflict have changed over time, the central factors dividing Zionists and Arabs in the Middle East have altered little and what factors are and why they have been so effective in frustrating every peace effort (Rapopet, 1989).

Hamas was founded in soon after the First Intifada broke out, as an offshoot of the Egyptian Muslim Brotherhood, which in its Gaza branch had previously been no confrontational toward Israel and hostile to the PLO. Co-founder Sheik Ahmed Yassin said in 1987, and the Hamas Charter affirmed in 1988, that Hamas was founded to liberate Palestine, including modern-day Israel, from Israeli occupation and to establish an Islamic state in the area that is now Israel, the West Bank and the Gaza Strip. The group has stated that it may accept a 10-year truce if Israel withdraws to the 1967 borders and allows Palestinian refugees from 1948, including their descendants, to return to what is now Israel, but that this would not mean recognition of Israel or the end of the conflict. Hamas's military wing objected to the truce offer.

Hamas's military wing has launched attacks against Israeli civilians and soldiers, often describing them as retaliatory, in particular for assassinations of the upper echelon of their leadership. Tactics have included suicide bombings and, since 2001, rocket attacks. Hamas's rocket arsenal, though mainly consisting of short-range homemade Qassam rockets, also includes long-range weapons that have reached major Israeli cities, including Tel Aviv and Haifa. The attacks on civilians have been condemned as war crimes and crimes against humanity by human rights groups such as Human Rights Watch. A 2017 Palestinian Center for Public Opinion poll in the Palestinian territories revealed that Hamas's violence and rhetoric against Israelis are unpopular and that most Palestinians would rather Hamas "accept a permanent two-state solution based on the 1967 borders (Bonney, 2004)."

In the January 2006 Palestinian parliamentary elections, Hamas won a plurality in the Palestinian Parliament, defeating the PLO-affiliated Fatah party. After the elections, the Quartet (the United States, Russia, United Nations, and European Union) made future foreign assistance to the PA conditional upon the government's commitment to nonviolence, recognition of the state of Israel, and acceptance of previous agreements. Hamas rejected those conditions, which led the Quartet to suspend its foreign assistance program and Israel to impose economic sanctions on the Hamas-led administration. In March 2007, a national unity government headed by Prime Minister Ismail Haniyeh of Hamas was briefly formed, but this failed to restart international financial assistance. Tensions over control of Palestinian security forces soon erupted in the 2007 Battle of Gaza, after which Hamas took control of Gaza, while its officials were ousted from government positions in the West Bank. Israel and Egypt then imposed an economic blockade of the Gaza Strip on the grounds that Fatah forces were no longer providing security there (Jankowski, 1997).

Founded by Hasan al-Banna in Egypt in 1928, the Muslim Brotherhood is the historical and ideological predecessor of Islamism in Palestine. The Palestinian question has been central to the movement since its inception. This centrality resulted in both Israel mistakenly characterized the Mujama as a social welfare organization and unlike the PLO uninterested in politics. In 1978, Israel's civil administration encouraged Sheikh Ahmed Yassin, the head of the Mujama and later the spiritual leader of Hamas, to register as a charitable society.

Ideological and some military support and culminate in the formation of a Palestinian Muslim Brotherhood organization. The new movement was characterized by religiously motivated social welfare activism. The religious motives of the movement are related to the concepts of Islamic umma or community and the notion of jihad. As a community Muslim is to defend themselves from aggression, secure freedom of belief, protect the message of Islam and relieve the oppressed and support them against their oppressors. The doctrinaire perspectives on the religious precepts of umma and jihad drive the Muslim Brotherhood's commitment to the Palestinian cause (Badawi \& Makdisi, 2007). 
To a lesser extent, the Muslim Brothers had national and political concerns that focused on the military and economic security of Egypt. They feared a Zionist state because they viewed it as an outpost of Western imperialism and as a barrier obstructing contact with Asia and Africa. Zionism was also viewed as a social threat, a potential source of apostasy and permissiveness (el-Awaisi, 1998).

The Muslim Brotherhood met in Haifa in 1946 and 1947 and committed itself to the defense of Palestine and to cooperation with the nationalist forces. The movement flourished as general respect and appreciation for its support grew. In 1947, the Brotherhood became active in public mobilization campaigns in preparation for Jihad and in disseminating anti-Zionist propaganda. The Brotherhood disseminated its message through the mosques. In the 1948, the movement put aside ideology and joined forces with national organizations even participating in the war.

After the 1948, war the movement was divided. The Muslim Brotherhood in the West Bank was incorporated into the Brotherhood in Jordan and the Brethren in Gaza came under Egyptian control. The movement in the West Bank adopted a political approach that focused on education, and charity. The Brothers in Jordan were conservative and quietist, more concerned with social issue and the building of an Islamic society. Its counterpart in Gaza took on revolutionary and military traits. The Brotherhood in the Gaza Strip was involved politically and militarily until 1954 when Nasser banned the organization. This led to the establishment of the National Liberation Movement, Fateh in 1958- Palestinian Islamists distanced themselves from the secular nationalism of Fateh. They refrained from engaging in the liberation struggle during the 1960's and 70's when Fateh came to dominate the PLO. The Brotherhood continued to play a passive role focusing on social rather than political issues. They built mosques, and social institution, Islamic student societies, clubs and charitable organizations. In the late 1980's the Muslim Brotherhood underwent an ideological transformation and became the Movement of Islamic Resistance, Hamas. This shift coincided with the outbreak of the Intifada and was accompanied by a marked change in the political practice of the movement. Led by Shaykh Ahmad Yasin, the Brotherhood embraced the principle of armed resistance and combined it with the social change thesis. Patriotism (wataniyah) was united with religion (da 'wa). After the signing of the Peace Accords in 1993 Hamas became the main opposition to the terms of self rule. As such, Hamas views itself as the legitimate alternative to Palestinian secular nationalism (Rane, Iium, \& Bond, 2008).

\section{The Hamas Charter: Ideological Goals versus Political Pragmatic}

In November 1988, the Palestinian National Council (PNC) of the PLO adopted a Declaration of Independence. This Declaration accepts UN Resolution 181 and UN Security Council Resolution 242. Resolution 181 calls for the division of Palestine into two states, one Jewish and one Arab, and 242 establishes the right of all states to live in peace and security within secure boundaries. In August of 1988 Harakat al-Muqiiwama al-Isliimiyya or the Islamic Resistance Movement emerged as a reaction to the Palestinian Declaration of Independence (Appendices one, three \&seven).

The 1988 charter identifies the movement and establishes its ideological and political goals:

Allah is its Goal.

The Messenger is its Leader.

The Qur'an is its Constitution. Jihad is its methodology, and Death for the sake of Allah is its most coveted desire. 
Like the Muslim Brotherhood, the ultimate goal of' Hamas is the establishment of an Islamic state. This can only be achieved through the liberation of all Palestine (Jordan River to the Mediterranean Sea) from the Zionist enemy. " Accordingly, the Charter establishes the land of Palestine:" upon all Muslim generations till the day of Resurrection" as an Islamic waqf or religious trust. The Palestinian cause is transformed into a religious cause, and jihad for the liberation of Palestine is made obligatory for every Muslim. Hamas also professes a social agenda. The movement calls for fundamental changes in the education system: to liberate it from the effects of the Ideological Invasion brought about at the hands of the Orientalists and Missionaries ...."

The ideology of Hamas developed in rivalry with the national factions within the PLO and came ,to refute Zionist-Israeli claims to the land (Litvak, 1998). At a time when the PLO appeared to be abandoning the armed struggle and the goal of liberation, Hamas stuck to the established national values (Mishal \& Avraham, 2000). Thus, under the leadership of Sheikh Ahmad Yasin, the Muslim Brotherhood changed radically and their covenant came to state that „Nationalism, from the point of the view of the Islamic Resistance Movement, is part of religion. Nothing in nationalism is more significant or important than waging jihad when an enemy treads on Muslim land. "For Islamic parties there is no difference between the land that was occupied in 1967 and in 1948 because they see it all as the God-given Islamic endowment or Waqf, and no individual has the right to cede any part of it to non-Muslims (Aggestam, 1998).

The Charter characterizes Jews as an oppressive enemy that robs Muslims of their lands and property, imprisons youth, make orphans of children, and issue tyrannical laws. According to the Charter, the Jews collectively own wealth and control the international press through the support of powerful enemies of Islam. Zionist are responsible for crimes from the Communist Revolution to the First World War and the destruction of the Islamic Caliphate. As a religion-political movement, Hamas is faced with conflicting ideological issues.

\section{The Coalition of Palestinian Nationalism and Islam}

The movement utilizes religious language in its charter and quotes the Qur'an and hadith (the prophet's sayings) leaving little room for political flexibility. It denies the possibility of any and all peace initiatives. As religious trust, Palestine can never be divided. Renouncing any part of Palestine or recognizing the state of Israel is kufur according to Hamas. However, although committed to an undivided Palestine, Hamas does not renounce the PLO (which has accepted a two state solution).

The PLO is referred to in the charter as father, brother, relative, or friend: Our nation is one, plight is one, destiny is one, and our enemy is the same... (Maghdasi, 1993).

Ideologically, the secular nationalism of the PLO is in total contradiction to Hamas "religious ideology. However, like its predecessor Hamss has been forced to alter its parochial beliefs. The Palestinian Muslim Brotherhood was constrained to adopt an Islamic endorsement of violence that is jihad against Israel.

Similarly, Hamas has also been forced to alter its ideology to suit the political realities of Palestine. The movement recognizes the nationalist character of the Palestinian struggle. Therefore, the charter makes concession to the PLO making nationalism (al-wataniyah) a component of the faith (Beverly, 2006).

In addition to its tacit support of the PLO, Hamas supports two conflicting obligations, an undivided Palestinian state and an Islamic community or ummii. Like its predecessor, the Muslim Brotherhood, Hamas simultaneously supports a universalist vision of Islamic fraternity and a particularistic vision of Palestinian nationalism. Although Hamas claims to represent ,true Islam its ideology is not an unchanging body of doctrine. Rather, it is something that evolves and changes based on pragmatic realities. Hamas ${ }^{\text {ee }}$ written 
manifesto is not the only tool for understanding the movement. Although the Charter establishes the ideological foundations of Hamas the movement's practice often strays from its doctrinaire goals. As a fundamentalist movement Hamas is influenced by an Islamic heritage, but as a national liberation movement it is implicated in secular, western, national ideas: Since its inception, Hamas has "Palestinianized ${ }^{\text {te }}$ the universal claim of Islam and given the movement a national-religious political profile (Klein, 2001). The national struggle of the PLO has been Islamized by Hamas: „So effective has Barnas become in setting the agenda of the Intifada that the PLO has been moved to invoke an Islamic discourse in its own pronouncements (Ibid). In this way, Hamas has Palestinianized Islam as opposed to Islamizing Palestine.

The Palestinianization of Islam occurred on three ideological levels. Hamas differentiates its political conditions from those in other Arab countries because Palestine is ruled by an internal (secular) enemy. Second, Palestinian land especially Jerusalem is portrayed as the center of national-religious identity. Finally, the jihad of the Intifida led by Hamas is equated with the struggle against the enemies of Islam. However, the movements' sacred obligations to an undivided Palestine clash with its obligation to Palestinian unity and Islamic fraternity. These contradictions are manifested in three modes of political action on the part of Hamas. Competition with the PLO, prevention of civil war with the PLO, and communication to reach equal status with the PLO. Hamas has adhered to these simultaneously creating antagonism (Hamami, 1994).

In 1990, Hamas groups in the West Bank clashed violently with Fath) the PLO's largest faction. The fighting came to an end one year later when Hamas and the PLO signed the "Alliance of Honor. "The PLO offered Hamas political representation and a chance to participate in its institutions. PLO leader Yasser" Arafat, offered Hamas seats in the 20th session of the Palestinian National Council (Ibid). Hamas agreed to participate on the condition that the PLO rescind its recognition of Israel and its readiness to make peace. The PLO rejected these conditions and the political clashes continued. Hamas' leadership is characterized by pragmatic leaders in Palestine and ,hard-line ee leaders in Jordan. Muhammad Nazal and Ibrahim Gawshah deported by Israel in 1989 direct the Hamas branch in Jordan.

Since the early $1990^{\text {ee }}$ s, Hamas leadership outside Palestine has mobilized the movement in a less ideological direction. Hamase doctrinal discourse (the rigid language of the Charter) has diminished in intensity. The struggle against Zionism has taken precedence over questions of ideology. This moderation is reflected in Hamas' practice. The organization has established contacts with Western states and international bodies especially in humanitarian matters. Further, a more nuanced understanding of Judaism, that separates the political movement of Zionism from the Jewish religion as a whole, has emerged (Hroub, 2000).

Hamas views the struggle with Israel as a long-term historic struggle. Victory requires the supremacy of Islam in the form of an Islamic state. However, the final victory of the Islamic umma over Zionism and Western ideals is viewed in future terms. Accordingly, the temporally victories of Zionism are not final because the historic conditions required for victory in a final sense have not yet been realized. When the Arab and Islamic renaissance takes place and the will of the umma united, victory (the liberation of all Palestine) will be attained. These views form the basis of Hamas position on a Palestinian state in part of historic Palestine, alongside a sovereign Israeli state (Shimoni, 2007).

Hamas differentiates a historic solution from an interim solution. The historic solution to the Palestinian problem is described as a long-term solution. The objectives of a long-term solution are to win back all of historic Palestine. The short-or medium-term solution is called the interim solution. This includes a commitment on the part of Palestinians to willingly accept a Palestinian or Arab or Islamic sovereignty over only part of the historic territory of Palestine alongside a sovereign Israeli state. 
This would be achieved through war or through peaceful means and is usually coupled with the idea of an armistice. Hamas bases its acceptance of an interim solution on the unconditional withdrawal of Zionist occupation forces from the West Bank and Gaza, including Jerusalem, the dismantling of settlements and the evacuation of settlers from those areas, and the holding of free general elections for a legislative body among the Palestinian people inside and outside Palestine. Acceptance is also based on the condition that there is to be no recognition of Israel. The eventual goal is an Islamic state in which Jews could live as citizens, not a sovereign Jewish entity (Hroub, 2000).

Hamas also bases its support on the consistency of the interim solution with shari 'ah. The interim solution is consistent with the Islamic concept of hudnah or armistice. Hudnah is not a peace treaty. According to Islamic law an armistice is an agreement limited for up to ten years. Hudnah does not require: „acceptance of the usurpation of our rights by the enemy. "(Hroub, 2000) Hence, an interim solution is not a permanent solution rather it is an agreement for a short period of time until political circumstances in Palestine change. Acceptance of an interim solution is contingent on the acceptance that armed resistance, the most prominent example being the Intifada; is the only way to achieve progress beyond the interim solution. These guidelines are summarized in a statement by the Political Bureau of Hamas dated April 1994(Usher, 1995) (Usher, 1995).

For the first time in the history of the movement an agenda in the form of a comprehensive solution was proposed. However, the statement by the Political Bureau like the ideology of Hamas is rife with ideological contradictions. It is difficult to reconcile the acceptance in principle of an interim solution with the continued belief in Palestine as an indivisible religious trust for all Muslim generations.

Hamas argues that it is willing to accept an interim solution, that is a declaration a willingness to accept a Palestinian, Arab or Islamic sovereignty over part of the historic territory of Palestine alongside a sovereign Israeli state. However, one of the conditions of accepting an interim solution is the nonrecognition of Israel. Hamas is simultaneously committed to a historic solution that calls for an Islamic state (to be established at a later date) that does not include a sovereign Jewish entity and an interim solution that recognizes a two state solution (Tibi, 1997).

In departing from the Brotherhood's ideological stances on territorial nationalism Hamas creates a new tradition. This invented tradition is here after considered an integral part of Palestinian national identity (Hobsbawm, 1991). Hamas conflates religion and territory. Islam allows for the creation of an identity and territory facilitates the substantive recognition of this identity. Thus, like the state of Israel, which garners its legitimacy through international recognition of its territorial sovereignty, Hamas aims for a similar recognition.

The organization has Islamized the struggle for Palestinian statehood, manipulating the interim solution into its version of Islamic law. In the interest of gaining ,, a place at the negotiating table, "Hamas has avoided direct confrontation with the PLO and moderated its tone toward the PA security forces (Usher, 1995). This has not stopped the PA from arresting and imprisoning Hamas militants.

\section{Conclusion}

Hamas, as its name (Islamic Resistance Movement) implies, aims to liberate Palestine from the Israeli occupation by resisting it. And according to Hamas armed branch Izz ad-Din al-Qassam Brigades: To contribute in the effort of liberating Palestine and restoring the rights of the Palestinian people under the sacred Islamic teachings of the Holy Quran, the Sunnah (traditions) of Prophet Muhammad (peace and blessings of Allah be upon him) and the traditions of Muslims rulers and scholars noted for their piety and dedication. 
Al-Qassam Brigades aims to liberate all of Palestine from what they describe as Zionist occupation, and to achieve the rights of the Palestinian people that were robbed by the occupation, and it consider itself part of the movement of a project of national liberation.

In Hamas in Politics Jeroen Gunning challenges the assumption that religion, violence and democracy are inherently incompatible and shows how many of these apparent contradictions flow from the interaction between Hamas s ideology, its local constituency and the nature of politics in Israel/Palestine. Drawing on interviews with members of Hamas and its critics, and a decade of close observation of the group, he offers a penetrating analysis of Hamas own understanding of its ideology and in particular the tension between its dual commitment to God and the people. The book explores what Hamas political practice says about its attitude towards democracy, religion and violence, providing a unique examination of the movements internal organization, how its leaders are selected and how decisions are made.

\section{References}

Aggestam, K. (1998). Reframing and Resolving Conflict Israeli-Palestinian Negotiations.

Badawi, I. El, \& Makdisi, S. (2007). Explaining the democracy deficit in the Arab world. The Quarterly Review of Economics and Finance, 46(5), 813-831. https://doi.org/10.1016/j.qref.2006.08.009

Beverly, E. (2006). Political Islam and the Palestinian-Israeli Conflict. Israel Affairs, 12(1), 65-85. https://doi.org/10.1080/13537120500381778

Bonney, R. (2004). Jihad: From the Quran to bin Laden. New York. New York: Palgrave.

el-Awaisi, A. al-F. M. (1998). The Muslim Brothers and the Palestine Question 1928-1947. New York: Tauris Acedemic Studies.

Faruqi, I. R. (1980). Islam and the Problem of Israel. London: The Islamic Council of Europe. kuala lumpur: The other press.

Hamami, J. (1994). al-Islamiyyun wal-Marhala al-Qadima. Nablus: Markaz al-Buhuth wal- Dirasat alFilastiniyya.

Hirst, D. (2003). The gun and the olive branch. London: Faber and Faber.

Hroub, K. (2000). Hamas Political Thought and Practice. Washington D.C: Institute for Palestine Studies.

Jankowski, J. (1997). Rethinking Nationalism in the Arab Middle East (I. Gershoni, ed.). New York: Columbia University Press.

Khashan, H. (2000). Policy focus: Arab attitudes toward Israel and peace. Washington, D.C: TheWashington Institute for Near East Policy.

Kohut, A., Doherty, C., \& Wike, R. (2012). No Global Warming Alarm in the US, China: America's Image Slips, but Allies Share US Concerns over Iran, Hamas, 15-Nation Pew Global Attitudes Survey. Pew Research Center, Washington, DC. Washington, DC: Pew Research Center. Retrieved May, 6(202), 2009.

Litvak, M. (1998). The Islamization of the Palestinian-Israeli conflict: the case of Hamas. Middle Eastern Studies, 34(1), 148-163. https://doi.org/10.1080/00263209808701214 
Maghdasi, M. (1993). The Charter of the Islamic Resistance Movement of Palestine. Journal of Palestine Studies, 22(5), 122-134.

Milton Edwards, B., \& Hinchcliffe, P. (2009). Jordan: A Hashemite Legacy (The Contemporary Middle East) (2nd ed.). Routledge.

Mishal, S., \& Avraham, S. (2000). The Palestinian Hamas: Vision, Violence, and Coexitence. New York: Columbia University Press.

Nusse, A. (1998). Muslim Palestine. The Ideology of Hamas. Oxon: RoutledgeCurzon,: Taylor and Francis Group.

Rane, H., Iium, B. H., \& Bond, M. A. (2008). Reconstructing Jihad amid Competing International Norms : Implications for a Resolution of the Israel-Palestine Conflict. (January).

Rapopet, A. (1989). The Origins of Violence: Approaches to the Study of Conflicttle. New York: Paragon House.

Rubenberg, C. (2003). The Palestinians: In search of a just peace. Boulder: Lynne Rienner.

Shimoni, G. (2007). Postcolonial Theory and the History of Zionism. Israel Affairs, 13(4), 859-871. https://doi.org/10.1080/13537120701445331

Tibi, B. (1997). Arab Nationalism (3rd ed.). New York: Martin's Press.

Usher, G. (1995). “What Kind of Nation? The Rise of Hamas in the Occupied Territories, ” in Political Islam: Essays from Middle East Report (J. Beinin \& J. Stork, eds.). Berkeley: University of California Press.

World Public Opinion.Org. (2006). International Poll: Most publics--including Americans - oppose taking sides in Israeli-Palestinian Conflict. Retrieved from http://www.worldpublicopinion.org

\section{Copyrights}

Copyright for this article is retained by the author(s), with first publication rights granted to the journal.

This is an open-access article distributed under the terms and conditions of the Creative Commons Attribution license (http://creativecommons.org/licenses/by/4.0/). 